\title{
RK-95113, a New Angiogenesis Inhibitor Produced by Aspergillus fumigatus
}

\author{
Yukihiro Asami, Hideaki Kakeya, Gen Okada, Masakazu Toi, Hiroyuki Osada
}

Received: July 27, 2006 / Accepted: October 17, 2006

(C) Japan Antibiotics Research Association

\begin{abstract}
We found that the strain Aspergillus fumigatus var. fumigatus RK95-113 produced a new angiogenesis inhibitor, RK-95113. Spectroscopic analyses identified the structure of RK-95113 as a new fumagillin-related small molecule. RK-95113 preferentially inhibited the growth of human umbilical vein endothelial cells (HUVECs) rather than that of human normal fibroblasts in cell proliferation assays and blocked endothlial cell migration induced by vascular endothelial growth factor (VEGF).
\end{abstract}

Keywords angiogenesis inhibitor, RK-95113, endothelial cells, migration, vascular endothelial growth factor (VEGF), Aspergillus fumigatus

Angiogenesis is a complex process involving several distinct and sequential steps, such as membrane degradation, migration (chemotaxis), proliferation, and the formation of capillary tubes in endothelial cells. Angiogenesis inhibition is a promising strategy for the treatment of cancer and several other diseases, including diabetic retinopathy and rheumatoid arthritis. Several angiogenesis inhibitors are undergoing clinical trials, including a neutralizing antibody against vascular endothelial growth factor (VEGF). Avastin (bevacizumab), in combination with 5-fluorouracil-based chemotherapy regimens, is now used to treat patients with metastatic colorectal cancer in the United States and Europe. However, it is of great interest to identify new angiogenesis inhibitors, as several small molecules with antiangiogenic activity are not clinically useful for toxicity and efficacy [1 5].

In this regard, we have commenced a screening program to identify and develop new angiogenesis inhibitors derived from microbial metabolites. Recently, we reported the identification of novel angiogenesis inhibitors, epoxyquinols A and B, epoxytwinol A, azaspirene, and RK-805, isolated from fungal metabolites [6 10]. In the course of our phenotypic screening for angiogenesis inhibitors, RK95113 (Fig. 1a) was discovered from the fermentation broth of Aspergillus fumigatus var. fumigatus RK95-113 (JCM 12527, FERM P-19233). The strain was isolated from soil collected in Wako, Saitama, Japan, and identified according to the methods of Klich and Pitt $[11,12]$ as well as by comparison with the Aspergillus Reference Cultures (http://www.cbs.knaw.nl/ICPA/) maintained in the Japan Collection of Microorganisms (JCM; http://www.jcm.riken. $\mathrm{jp} / \mathrm{JCM} / \mathrm{aspref.html}$ ). The strain was inoculated into two 30-liter jar fermenters, each containing 15 liters of the culture medium, as previously described [10]. Further work on the culture broth led to the isolation of RK-95113 [13].

The molecular formula of RK-95113 was determined to be $\mathrm{C}_{24} \mathrm{H}_{34} \mathrm{O}_{5}$ based on HREI-MS data $\left(\mathrm{M}^{+} ; \mathrm{m} / z\right.$ 402.2393, calcd. for $\mathrm{C}_{24} \mathrm{H}_{34} \mathrm{O}_{5}$ : 402.2407). All one-bond ${ }^{1} \mathrm{H}-{ }^{13} \mathrm{C}$ connections in RK-95113 were elucidated by the PFGHMQC and DEPT experiments. The NMR data and the molecular formula indicated the presence of one methoxy, four methyls, four methylenes, four $s p^{3}$ methines, seven $s p^{2}$
H. Kakeya (Corresponding author), Y. Asami, H. Osada: Antibiotics Laboratory, Discovery Research Institute (DRI), RIKEN, 2-1 Hirosawa, Wako, Saitama 351-0198, Japan, E-mail: hkakeya@riken.jp
G. Okada: Microbe Division, Japan Collection of Microorganisms, RIKEN BioResource Center, 2-1 Hirosawa, Wako, Saitama 351-0198, Japan

M. Toi: Tokyo Metropolitan Komagome Hospital, 3-18-22 Honkomagome, Bunkyo-ku, Tokyo 113-8677, Japan 
a
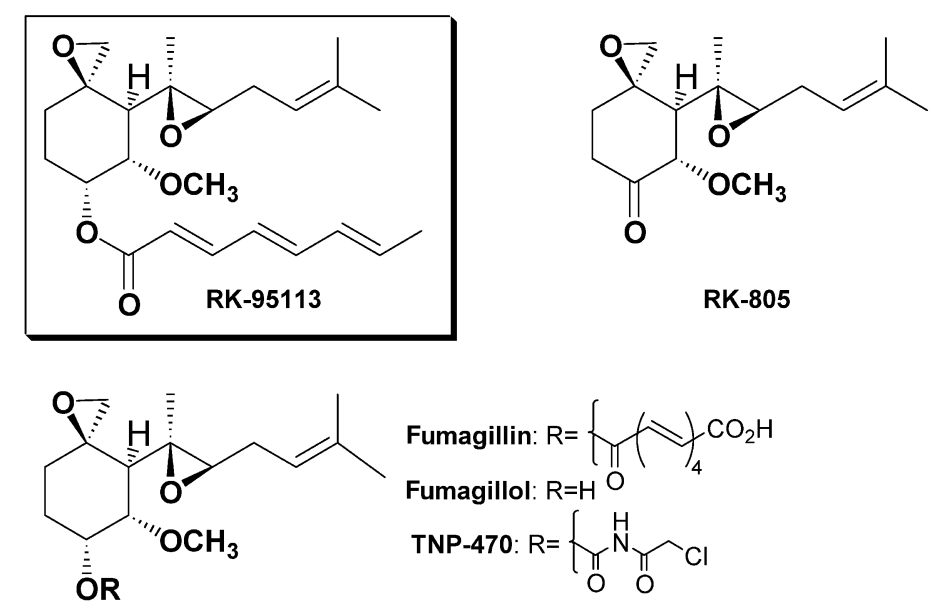

b

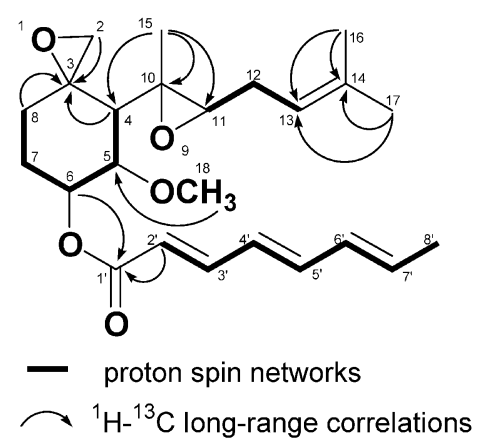

C

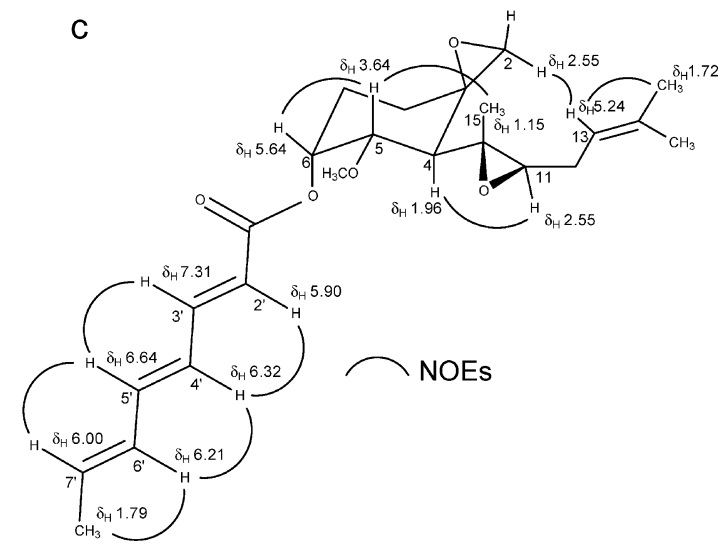

Fig. 1. (a) Structures of RK-95113, RK-805, fumagillin, fumagillol, and TNP-470. (b) Key correlations in PFG-DQFCOSY and PFG-HMBC spectra in RK-95113. (c) Key NOE data for RK-95113.

methines, and four quaternary carbons including a carbonyl carbon [14]. ${ }^{1} \mathrm{H}-{ }^{1} \mathrm{H}$ correlations in PFG-DQFCOSY (Fig. 1b), $\mathrm{H}-11$ through $\mathrm{H}-13$ and $\mathrm{H}-2^{\prime}$ through $\mathrm{H}-8^{\prime}$, indicated the presence of an alkenyl moiety including a terminal methyl proton. Also, long-range couplings from $\mathrm{H}-15$ to $\mathrm{C}$ 4, C-10, and C-11; from $\mathrm{H}-16$ and $\mathrm{H}-17$ to $\mathrm{C}-13$ and $\mathrm{C}-14$; and from $\mathrm{H}-2^{\prime}$ to carbonyl carbon at $\mathrm{C}-1^{\prime}$ were observed in the PFG-HMBC experiment (Fig. 1b). Thus, the linkages from $\mathrm{C}-10$ to $\mathrm{C}-17$ and from $\mathrm{C}-\mathrm{1}^{\prime}$ to $\mathrm{C}-8^{\prime}$ were established. The cyclohexanol skeleton was confirmed by ${ }^{1} \mathrm{H}-{ }^{1} \mathrm{H}$ corrleations in PFG-DQFCOSY: H-4 through H-8, as well as by ${ }^{1} \mathrm{H}-{ }^{13} \mathrm{C}$ correlations in the PFG-HMBC spectra: the strong two- and three-bond ${ }^{1} \mathrm{H}-{ }^{13} \mathrm{C}$ correlations from $\mathrm{H}-18$ of the methoxy proton signal to $\mathrm{C}-5$ and from the proton at H-6 to the carbonyl carbon at the $\mathrm{C}-1^{\prime}$ position. The exocyclic epoxide ring on cyclohexanol was confirmed by the chemical shifts, coupling constants, and two strong correlations from $\mathrm{H}-2, \mathrm{H}-4$, and $\mathrm{H}-8$ to $\mathrm{C}-3$ in the PFGHMBC experiment. Thus, the planar structure of RK-
95113 with the fumagillol nucleus and alkenyl moiety was established. The relative stereochemistry of RK-95113 was elucidated by NOE experiments (Fig. 1c). Significant NOEs between H-5 $\left(\delta_{\mathrm{H}} 3.64\right)$ and H-15 $\left(\delta_{\mathrm{H}} 1.15\right), \mathrm{H}-5$ and H-6 $\left(\delta_{\mathrm{H}} 5.64\right), \mathrm{H}-4\left(\delta_{\mathrm{H}} 1.96\right)$ and $\mathrm{H}-11\left(\delta_{\mathrm{H}} 2.55\right)$, and $\mathrm{H}-13$ $\left(\delta_{\mathrm{H}} 5.24\right)$ and $\mathrm{H}-2 \mathrm{a}\left(\delta_{\mathrm{H}} 2.55\right)$ were observed, indicating that H-4 and H-5 were both axial and H-6 was equatorial. The geometry of the three conjugated double bonds was determined as all- $E$ on the basis of the coupling constants $\left(J_{2^{\prime}, 3^{\prime}}=15.2 \mathrm{~Hz}, J_{4^{\prime}, 5^{\prime}}=14.2 \mathrm{~Hz}\right.$, and $\left.J_{6^{\prime}, 7^{\prime}}=14.4 \mathrm{~Hz}\right)$ and the NOE correlations between H-2' and H-4', H- $3^{\prime}$ and H-5', $\mathrm{H}-4^{\prime}$ and H-6', H-5' and H-7', and H-6 $6^{\prime}$ and $\mathrm{H}-8^{\prime}$. Therefore, the relative stereochemistry of RK-95113 was unambiguously determined as shown in Fig. 1a.

We tested the effects of RK-95113 on the growth of human umbilical vein endothlial cells (HUVECs) and normal human fibroblast WI-38 cells in a proliferation assay. The $\mathrm{IC}_{50}$ values in the HUVECs of RK-95113, RK805 , fumagillin, and TNP-470 were $0.1,0.03,0.5$, and 
a

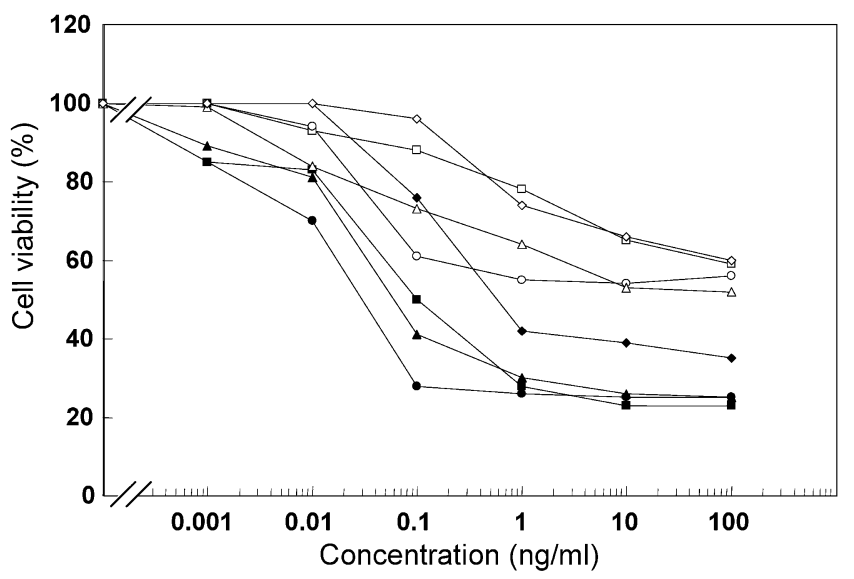

b

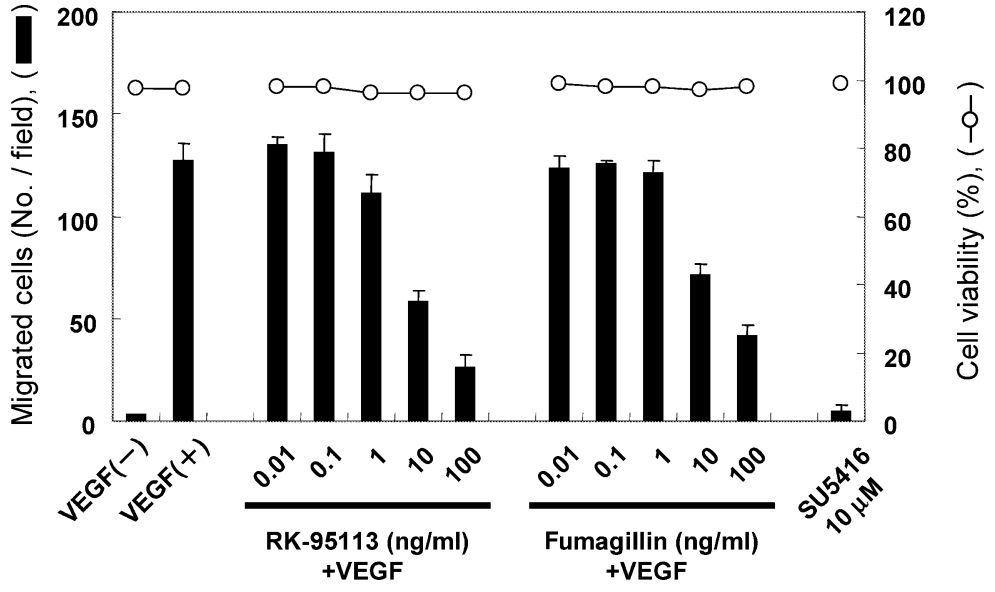

Fig. 2. RK-95113 effectively inhibits the growth and VEGF-induced migration of HUVECs.

(a) HUVECs and WI-38 cells were seeded on 96-well microplates $\left(1.5 \times 10^{3}\right.$ cells per well), respectively. Test compounds were dissolved in methanol at appropriate concentrations and were treated for 96 hours (both HUVECs and WI-38 cells). Cell proliferation assays were carried out by the WST-8 ${ }^{\text {TM }}$ (Nacalai Tesque, Kyoto, Japan) protocol. The growth of HUVECs: $\mathbf{\square}, \mathrm{RK}-95113$ (IC $\left.\mathrm{C}_{50}: 0.1 \mathrm{ng} / \mathrm{ml}\right)$;, RK-805 $\left(I C_{50}: 0.03 \mathrm{ng} / \mathrm{ml}\right) ; \boldsymbol{\Lambda}$, TNP-470 (IC $\left.{ }_{50}: 0.06 \mathrm{ng} / \mathrm{ml}\right) ;$, fumagillin $\left(I C_{50}: 0.5 \mathrm{ng} / \mathrm{ml}\right)$. The growth of Wl-38 cells: $\square$, RK-95113 (IC $\left.50:>100 \mathrm{ng} / \mathrm{ml}\right)$; O, RK-805 $\left(I C_{50}:>100 \mathrm{ng} / \mathrm{ml}\right) ; \triangle$, TNP-470 $\left(I C_{50}:>100 \mathrm{ng} / \mathrm{ml}\right)$; $\diamond$, fumagillin $\left(I C_{50}:>100 \mathrm{ng} / \mathrm{ml}\right)$. (b) HUVECs ( $1 \times 10^{5}$ cells per well) suspended in Humedia-EG2 medium (Kurabo, Osaka, Japan) with various concentrations of test compounds were added to the upper compartment of a Chemotaxicell chamber (Kurabo) and incubated with HuMedia-EG2 medium containing $12.5 \mathrm{ng} / \mathrm{ml}$ of VEGF in the lower compartment for 18 hours at $37^{\circ} \mathrm{C}$ in a $5 \% \mathrm{CO}_{2}$ atmosphere. The filter was fixed with $\mathrm{MeOH}$ and stained with Wright solution. The cells on the upper surface of the filter were removed by wiping with cotton swabs. Cells that migrated through the filter to the areas of the lower surface were counted manually under a microscope at a magnification of $\times 100$. Values are means \pm S.D. for triplicate samples.

$0.06 \mathrm{ng} / \mathrm{ml}$, respectively, whereas they did not exhibit remarkable inhibitory activity in WI-38 cells even at $100 \mathrm{ng} / \mathrm{ml}$, indicating that all these compounds exhibited preferential inhibitory activities in HUVECs (Fig. 2a).

Next we performed the cell migration assay. VEGF significantly induced cell migration, where as $10 \mu \mathrm{M}$ of SU5614, an inhibitor of VEGF receptor tyrosine kinase, inhibited the VEGF-induced cell migration (Fig. 2b) [15]. RK-95113 also inhibited cell migration induced by VEGF in a dose-dependent manner without showing significant cell toxicity; this result was estimated by trypan blue dye exclusion assay [10]. The $\mathrm{ED}_{50}$ value of RK-95113 was $c a$. $10 \mathrm{ng} / \mathrm{ml}$, as shown in Fig. 2b. Fumagillin exhibited almost the same inhibitory activity in this assay. These results suggested that RK-95113 blocked the function of endothelial cell migration activated by VEGF.

RK-95113 belongs to the fumagillin family including FR-111142 [16] and Sch528647 [17]. At the molecular level, one of the direct targets for fumagillin and its analogues, including RK-805 and ovalicin, has been 
identified as methionine aminopeptidase-2 (MetAP2), a dimetalloprotease catalyzing the removal of $\mathrm{N}$-terminal methionine in newly formed polypeptide chains [10, 18 20]. In particular, the spiro-epoxide moiety plays a crucial role by creating a covalent bond with a histidine residue (His231) of the active site in human MetAP2. The X-ray crystal structure of fumagillin with human MetAP2 also reveals that a water molecule forms hydrogen bonds with the oxygens of the methoxy group and the epoxide of the alkyl side chain in fumagillin, which plays a role in stabilizing His231 [21]. RK-95113 has a common moiety with fumagillin and its analogue for the above binding with human MetAP2, while the alkenyl side chain, including an octa-2,4,6-trienoic acid ester of RK-95113, is different from the others, especially regarding in the hydrophobicity and polarity. This suggests that RK-95113 may directly inhibit MetAP2 and may have different rates of cellular uptake and metabolism in intact cells. Meanwhile, it is not fully established why endothelial cell growth requires MetAP2, although the ability of fumagillin and its analogues to inhibit endothelial cell growth is related to their ability to inhibit MetAP2 activity in a p53-dependent manner [22, 23]. Moreover, very recently we found that fumagillin and TNP-470 suppress human immunodeficiency virus I (HIV-1) infection of macrophages though the inhibition of HIV-1 viral protein R (VPR) activity, independently from the MetAP2 pathway [24]. Therefore, further comprehensive chemical and biological studies of fumagillin and its analogues, including RK-95113, might shed light on these pivotal events in relation to chemotherapy for angiogenesis-related diseases as well as for HIV-1.

Acknowledgements This work was supported in part by a Grant-in-Aid from the Ministry of Education, Culture, Sports, Science, and Technology of Japan, by a Grant-in-Aid for Cancer Research from the Ministry of Health, Labour, and Welfare of Japan, by the Chemical Biology Project (RIKEN), and by funding from the Special Postdoctoral Researchers Program (to Y. A.).

References

1. Kerbel R, Folkman J. Clinical translation of angiogenesis inhibitors. Nature Rev Cancer 2: 727-739 (2002)

2. Cristofanilli M, Charnsangavej C, Hortobagyi G. Angiogenesis modulation in cancer research: novel clinical approaches. Nature Rev Drug Discov 1: 415-426 (2002)

3. Ferrara N, Kerbel RS. Angiogenesis as a therapeutic target. Nature 438: 964-974 (2005)

4. Shibuya M, Claesson-Welsh L. Signal transduction by VEGF receptors in regulation of angiogenesis and lymphangiogenesis. Exp Cell Res 312: 549-560 (2006)

5. Folkman J. Angiogenesis. Annu Rev Med 57: 1-18 (2006)

6. Kakeya H, Onose R, Koshino H, Yoshida A, Kobayashi K, Kageyama S-I, Osada H. Epoxyquinol A, a highly functionalized pentaketide dimer with antiangiogenic activity isolated from fungal metabolites. J Am Chem Soc 124: 3496-3497 (2002)

7. Kakeya H, Onose R, Yoshida A, Koshino H, Osada H. Epoxyquinol B, a fungal metabolite with a potent antiangiogenic activity. J Antibiot 55: 829-831 (2002)

8. Kakeya H, Onose R, Koshino H, Osada H. Epoxytwinol A, a novel unique angiogenesis inhibitor with $C_{2}$ symmetry, produced by a fungus. Chem Commun 2005: 2575-2577 (2005)

9. Asami Y, Kakeya H, Onose R, Yoshida A, Matsuzaki H, Osada H. Azaspirene: a novel angiogenesis inhibitor containing a 1-oxa-7-azaspiro[4.4]non-2-ene-4,6-dione skeleton produced by the fungus Neosartorya sp. Org Lett 4: 2845-2848 (2002)

10. Asami Y, Kakeya H, Onose R, Chang YH, Toi M, Osada H. RK-805, an endothelial-cell-growth inhibitor produced by Neosartorya sp., and a docking model with methionine aminopeptidase-2. Tetrahedron 60: 7085-7091 (2004)

11. Klich MA, Pitt JI. A Laboratory guide to common Aspergillus species and their teleomorphs. Commonwealth Scientific and Industrial Research Organization, Division of Food Processing, North Ryde, Australia (1988)

12. Klich MA. Identification of common Aspergillus species. Centraalbureau voor Schimmelcultures, Utrecht, The Netherlands (2002)

13. The culture broth was centrifuged and the supernatant was adjusted to $\mathrm{pH}$ 3.0. The supernatant was extracted with an equal volume of ethyl acetate. The organic layer was concentrated in vacuo to dryness. The concentrate material was applied to silica gel column chromatography. The materials were eluted with a stepwise gradient of $\mathrm{CHCl}_{3}$ $\mathrm{CH}_{3} \mathrm{OH}\left(0 \sim 100 \% \mathrm{MeOH}\right.$ in $\left.\mathrm{CHCl}_{3}\right)$. The active fraction was concentrated in vacuo to yield a crude material. Further purification of RK-95113 was carried out by HPLC (PEGASIL ODS, 20 i.d. $\times 250 \mathrm{~mm}$, Senshu Scientific Co. Ltd., Tokyo) with a linear gradient solvent system of $\mathrm{CH}_{3} \mathrm{CN}$ - water (from 20:80 to $0: 100$ for 40 minutes) at a flow rate of $9.0 \mathrm{ml} /$ minute to give a yellow powder. Finally, $2.2 \mathrm{mg}$ of RK-95113 was separated by preparative TLC with $n$-hexane-ethyl acetate $(3: 1)$. RK-95113 was obtained as a colorless amorphous powder, that is soluble in $\mathrm{MeOH}$, acetone, and DMSO but not in $n$-hexane and $\mathrm{H}_{2} \mathrm{O}$. The $\mathrm{Rf}$ value in the solvent system $\left(\mathrm{CHCl}_{3}-\mathrm{MeOH}, 50: 1\right)$ was 0.63 on a silica gel TLC (Merck 60 F254); $[\alpha]_{\mathrm{D}}{ }^{23}-40.0^{\circ}$ $(c=0.035, \mathrm{EtOH}) ; \mathrm{IR} ; \mathrm{KBr} v_{\max } 2920,1700,1610,1265$, $1225,1125,1005 \mathrm{~cm}^{-1}$; UV (MeOH) $\lambda_{\max } \mathrm{nm}(\varepsilon) 300$ (47830).

14. ${ }^{1} \mathrm{H}$ NMR data of RK-95113: (500 MHz in acetone- $\left.d_{6}\right), \delta_{\mathrm{H}}$ 1.15 (s, 3H, H-15), 1.29 (m, 2H, H-8), 1.64 (s, 3H, H-16), 1.72 (s, 3H, H-17), 1.79 (d, 3H, J=6.7 Hz, H-8'), 1.88 (m, 
2H, H-7), 1.96 (d, 1H, J=10.40 Hz, H-4), 2.22 (m, 2H, H12), 2.55 (m, 1H, H-11), 2.55 (m, 1H, H-2a), 2.96 (d, 1H, $J=3.10 \mathrm{~Hz}, \mathrm{H}-2 \mathrm{~b}), 3.35$ (s, 3H, H-18), 3.64 (d, 1H, $J=10.40 \mathrm{~Hz}, \mathrm{H}-5$ ), 5.24 (br s, 1H, H-13), 5.64 (br s, $1 \mathrm{H}, \mathrm{H}-$ 6), 5.90 (d, $\left.1 \mathrm{H}, J=15.2 \mathrm{~Hz}, \mathrm{H}-2^{\prime}\right), 6.00$ (dq, $1 \mathrm{H}, J=14.4 \mathrm{~Hz}$, $\left.6.7 \mathrm{~Hz}, \mathrm{H}-7^{\prime}\right), 6.21$ (dd, 1H, $\left.J=14.4 \mathrm{~Hz}, 11.1 \mathrm{~Hz}, \mathrm{H}-6^{\prime}\right), 6.32$ (dd, $\left.1 \mathrm{H}, J=14.2 \mathrm{~Hz}, 11.8 \mathrm{~Hz}, \mathrm{H}-4^{\prime}\right), 6.64(\mathrm{dd}, 1 \mathrm{H}$, $\left.J=14.2 \mathrm{~Hz}, 11.1 \mathrm{~Hz}, \mathrm{H}-5^{\prime}\right), 7.31$ (dd, $1 \mathrm{H}, J=15.2 \mathrm{~Hz}$, $\left.11.8 \mathrm{~Hz}, \mathrm{H}-3^{\prime}\right) .{ }^{13} \mathrm{C}$ NMR data of RK-95113: (125 MHz in acetone- $d_{6}$ ), $\delta_{\mathrm{C}} 14.53$ (q, C-15), 17.98 (q, C-16), 18.53 (q, C-8'), 25.80 (q, C-17), 26.43 (t, C-7), 28.11 (t, C-12), 30.10 (t, C-8), 49.08 (d, C-4), 51.57 (t, C-2), 56.64 (q, C-18), 58.88 (s, C-10), 60.14 (s, C-3), 60.75 (d, C-11), 67.37 (d, C6), 80.31 (d, C-5), 120.34 (d, C-13), 121.21 (d, C-2'), 128.58 (d, C-4'), 132.27 (d, C-6'), 134.67 (s, C-14), 135.57 (d, C7'), 141.98 (d, C-5'), 145.59 (d, C-3'), 166.48 (s, C-1').

15. Sun L, Tran N, Tang F, App H, Hirth P, McMahon G, Tang C. Synthesis and biological evaluations of 3-substituted indolin-2-ones: a novel class of tyrosine kinase inhibitors that exhibit selectively toward particular receptor tyrosine kinases. J Med Chem 41: 2588-2603 (1998)

16. Otsuka T, Shibata T, Tsurumi Y, Takase S, Okuhara M, Terano H, Kohsaka M, Imanaka H. A new angiogenesis inhibitor, FR-111142. J Antibiot 45: 348-354 (1992)

17. Chu M, Mierzwa R, He L, Xu L, Patel M, Patel D, Chan TM. Structure of Sch528647: a new antitumor antibiotic related to fumagillin. J Antibiot 54: 1096-1099 (2001)
18. Griffith EC, Su Z, Niwayama S, Ramsay CA, Chang YH, Liu JO. Molecular recognition of angiogenesis inhibitors fumagillin and ovalicin by methionine aminopeptidase 2 . Proc Natl Acad Sci USA 95: 15183-15188 (1998)

19. Zhang Y, Griffith EC, Sage J, Jacks T, Liu JO. Cell cycle inhibition by the anti-angiogenic agent TNP-470 is mediated by $\mathrm{p} 53$ and $\mathrm{p} 21^{\mathrm{WAF} 1 / \mathrm{CIP} 1}$. Proc Natl Acad Sci USA 97: 6427-6432 (2000)

20. Sin N, Meng L, Wang MQ, Wen JJ, Bornmann WG, Crews $\mathrm{CM}$. The anti-angiogenic agent fumagillin covalently binds and inhibits the methionine aminopeptidase, MetAP-2. Proc Natl Acad Sci USA 94: 6099-6103 (1997)

21. Liu S, Widom J, Kemp CW, Crews CM, Clardy J. Structure of human methionine aminopeptidase-2 complexed with fumagillin. Science 282: 1324-1327 (1998)

22. Kim S, LaMontagne K, Sabio M, Sharma S, Versace RW, Yusuff N, Phillips PE. Depletion of methionine aminopeptidase 2 does not alter cell response to fumagillin or bengamides. Cancer Res 64: 2984-2987 (2004)

23. Bernier SG, Taghizadeh N, Thompson CD, Westlin WF, Hannig G. Methionine aminopeptidase type I and type II are essential to control cell proliferation. J Cell Biochem 95: 1191-1203 (2005)

24. Watanabe N, Nishihara Y, Yamaguchi T, Koito A, Miyoshi H, Kakeya H, Osada H. Fumagillin suppresses HIV-1 infection of macrophages through the inhibition of $\mathrm{Vpr}$ activity. FEBS Lett 580: 2598-2602 (2006) 